\title{
Access Routes
}

to the

\section{United States}

Geological Survey's

National

Center,

Reston,

Virginia

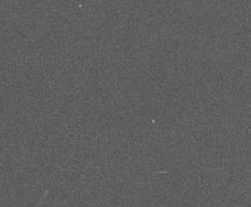

U. $\mathrm{s}$.

Department of the Interior Geological Survey 


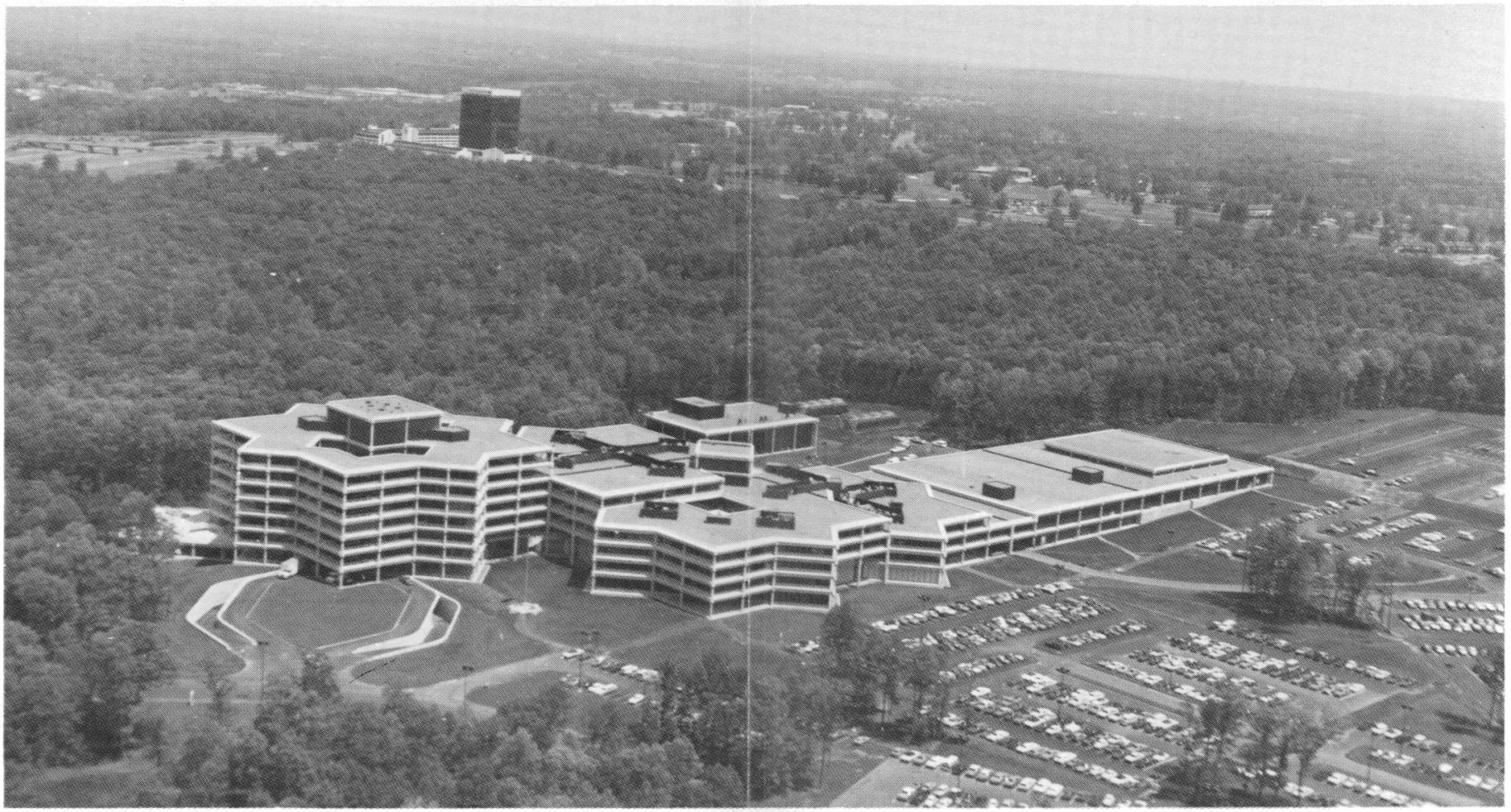

The National Center: The U.S. Geological Survey, established in 1879 as a bureau in the Department of the Interior, is one of the Federal Government's major earth science research and fact-finding agencies. By 1960, the continued growth of the Survey's natural resources and environmental programs and activities led to the agency's headquarters personnel being housed in more than 30 different buildings scattered throughout the Washington, D.C. metropolitan area. In 1962, Congress approved the construction of a National Center to consolidate the overall Survey's headquarters effort. A site in Reston's industrial/ educational complex was selected and on July 15 , 1971, ground was broken for the John Wesley Powell Federal Building.

Now more than 2,500 Survey employees are housed in this 1-million-square-foot structure, which is situated in a 105-acre wooded area. A separate building houses the Solid State Physics Laboratory in the same area.
Access Routes: The U.S.Geological Survey's National Center is located in the new town of Reston, Virginia, which is about 18 miles west of Washington, D.C., and 5 miles east of the Dulles International Airport. Reston is approximately 20 minutes from the Capital Beltway (Interstate 495), and can be easily reached by Routes 7 and 606; or by Routes $66,50,608$, and 602. The National Center is about $1 / 2$ mile west of the intersection of Reston Avenue (Route 602) and Sunrise Valley Drive.

Reston, Virginia: This planned community was founded in 1962 on 7,400 acres (11.5 square miles) in Fairfax County, Virginia. Gently rolling, wooded hills surround the community. Reston itself is built around four mini-malls and a separate industrial park. About 200 firms and associations have located at the park.

Accomodations: Several inns and motels are conveniently located in the area surrounding Reston. A few of them provide bus service for visitors to the Center. 
Transportation: The National Center is reached most conveniently by automobile. The Reston Commuter Bus System offers over 30 Express Commuter buses to and from Washington, D.C., daily. Reston is also served by two Washington Metro bus routes that originate from the main bus terminal in Washington, D.C. The Common Ground bus, originating at the Lake Anne Village Center, provides transportation within Reston. The Geological Survey provides a shuttle service between the Interior Building in Washington, D.C., and the National Center for Government employees and visitors.
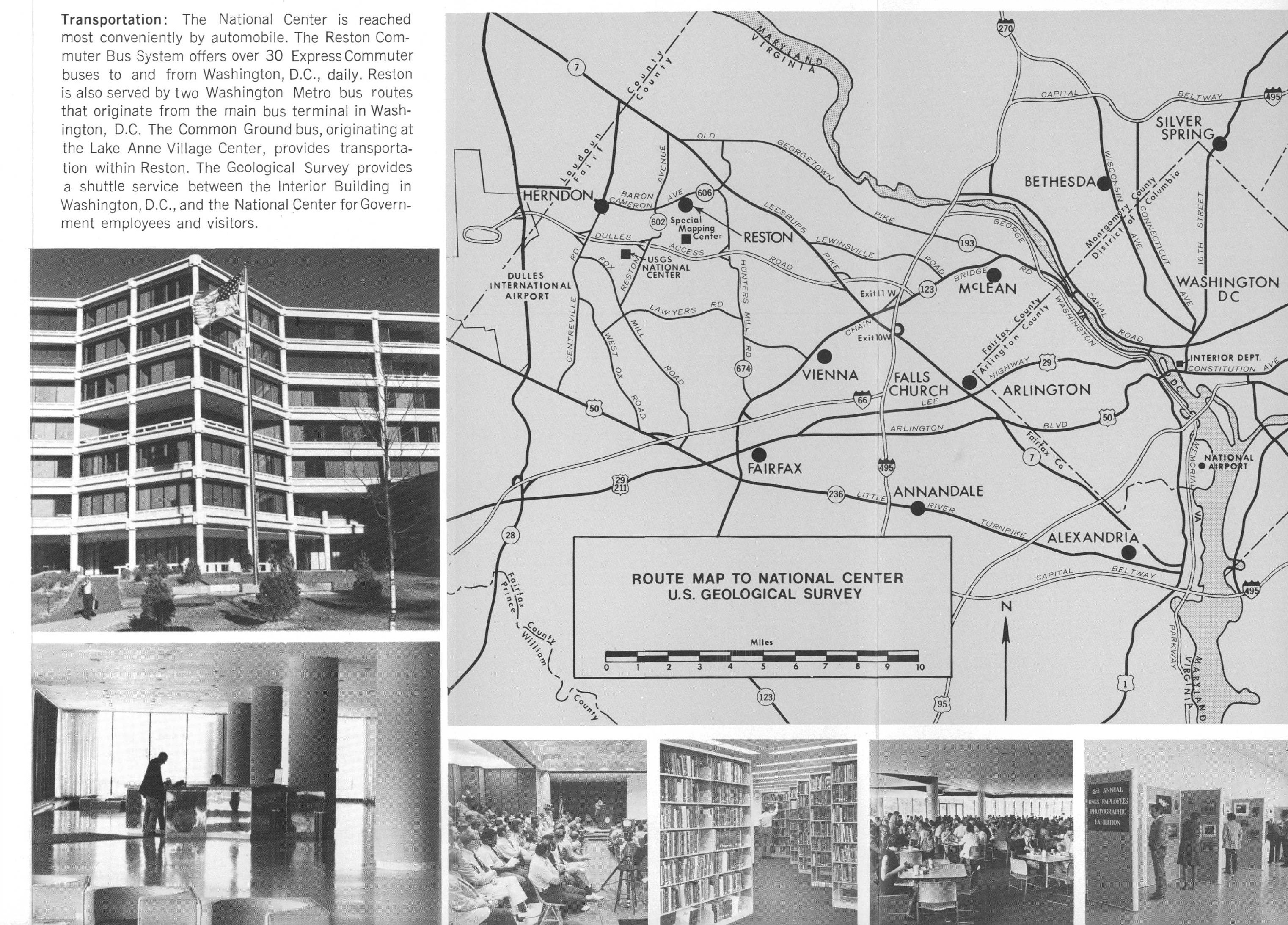


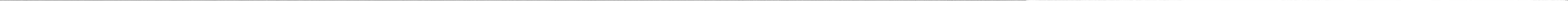


As the Waftonfs princtial conservation agency, the Departs ment of the Infertor has responsibility for most of our naftionally auned publite lands and natural resources. Thts tholudes fosterting the wisest use of our land and water resources, protecting our fish and wildilie, preserving the envitronmental and cultural values of our national parks and Gistortcal places, and proviting Tor the entoyment of life through outdoos recreafton, the Departs memt assesses our energy and mineral resources and works to assure that theth devetopment is to the best inferests of all our people The Department also thas a majos responsibility for Amertican Indian reservafion communifies and tor people who litve

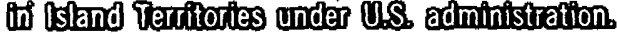

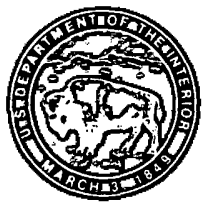

Cecin D Andrus, Secretary U.S. Department of the linteriors

VE. McKelvey. Director Geologrcal Survey

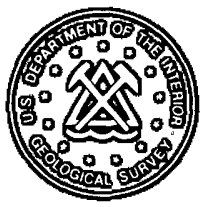

